\title{
KONTRIBUSI METODE PEMBELAJARAN, MOTIVASI BELAJAR DAN LATAR BELAKANG JURUSAN DI SEKOLAH MENENGAH TERHADAP PRESTASI BELAJAR MAHASISWA AKPER PANTI KOSALA SURAKARTA
}

\author{
Endang Dwi Ningsih ${ }^{1}$, Rizky Fajar Septiana ${ }^{2}$
}

\begin{abstract}
Background: a Learning achievement is inseparable from a learning activities because a learning process must provide a learning outcomes. By a high learning achievement indicates that the students have a good understanding of the knowledge. The learning achievement of a person is determined by internal and external factors that concerning three fundamental aspects of the learning process are namely the input, the process and the output. On the input aspects the determinant are the individual background, the facilitator, the method, the learning motivation and environment in which influencing the learning process so as to give output In the form of the learning achievement. Related to the above, the researcher is interested to do a research that concerning about the contribution of the learning method, the learning motivation and the majors study Background at the high School to the learning achievement of AKPER Panti Kosala Surakarta students. Research objectives: to know the contribution of the learning method, the learning motivation and the background of the majors study at the high school to the student learning achievement of AKPER Panti Kosala Surakarta students.

Research subject: research sample of 162 students of AKPER Panti Kosala Surakarta. Sampling by simple random sampling.

Results : by multivariate test with the double logistic regression test, show the value Negelkerke R Square $18,7 \%$.

Conclusion : That the variable of the learning method, the learning motivation and the background of majors study at the high school are jointly affect the learning achievement equal to $18,7 \%$ and the rest of which is $81,3 \%$ affected by other variable out of the research.
\end{abstract}

Keywords: The Learning Method, The Learning Motivation, The Background of the majors study at the high school and The Learning Achievement

\section{PENDAHULUAN}

Pada akhir paham behaviorisme, pendekatan pembelajaran didominasi oleh pembelajaran berbasis guru dimana guru lebih banyak melakukan kegiatan belajar mengajar dengan bentuk ceramah (teacher centered learning). Dengan munculnya paham kognitivisme dan konstruktivisme pendekatan berubah menjadi pembelajaran berbasis siswa/mahasiswa dimana siswa didorong untuk terlibat secara aktif dalam membangun pengetahuan, sikap dan perilakunya (student centered learning).

Berpangkal dari SCL inilah John Dewey sebagai tokoh pragmatisme, dalam kaitannya dengan pembelajaran memberi slogan "belajar dengan melakukan (learning by doing)" yang bermakna siswa harus aktif dalam berbagai pembicaraan pembelajaran (Warsono dan Hariyanto, 2014).

Sasaran utama pembelajaran adalah mendeskripsikan strategi pembelajaran yang optimal untuk mendorong prakarsa dan memudahkan belajar. Bahwa pembelajaran menaruh perhatian pada upaya untuk meningkatkan pemahaman dan memperbaiki proses pembelajaran sehingga menghasilkan output belajar berupa 
prestasi yang diharapkan sesuai tujuannya (Uno, 2015).

Penelitian oleh Nurhuda (2012), menunjukkan bahwa dalam pembelajaran akan diperoleh hasil belajar yang baik apabila dalam menyampaikan materi guru dapat menerapkan metode pembelajaran yang sesuai dengan karakteristik siswa, metode pembelajaran tertentu pada kelompok subyek yang berbeda karakteristiknya akan memberi hasil belajar berbeda pula. Prestasi belajar merupakan hal yang tidak dapat dipisahkan dari kegiatan belajar karena suatu proses belajar harus memberi hasil belajar. Dengan prestasi belajar yang tinggi para siswa/mahasiswa mempunyai indikasi berpengetahuan yang baik. Prestasi belajar seseorang ditentukan oleh faktor internal maupun eksternal yang menyangkut tiga komponen yaitu input, proses dan output yang menyangkut latar belakang individu, fasilitator, metode, minat/motivasi belajar dan lingkungan sehingga memberi output berupa hasil/prestasi belajar (Sunaryo, 2013).

Menurut Wahab (2015), metode pembelajaran adalah suatu cara yang digunakan untuk memberikan kesempatan seluas-luasnya kepada siswa dalam belajar. Metode pengajaran adalah suatu cara yang digunakan oleh guru agar siswa dapat belajar seluas-luasnya dalam rangka mencapai tujuan pengajaran secara efektif. Sebagaimana penelitian yang dilakukan oleh Widodo (2013), bahwa penerapan metode pembelajaran kolaboratif berdampak positif dalam meningkatkan keaktifan siswa baik dari ranah afektif maupun psikomotoris sehingga terbukti dapat meningkatkan prestasi belajar siswa.

Tujuan belajar diharapkan dapat menciptakan manusia yang percaya diri pada kemampuan diri sendiri, sedangkan belajar untuk hidup $\begin{array}{lcr}\text { bersama } & \text { diharapkan } & \text { dapat } \\ \text { menciptakan } & \text { manusia } & \text { yang } \\ \text { mempunyai } & \text { daya saing, } & \text { daya }\end{array}$ penyesuaian dan daya kerja sama yang tinggi. Maka untuk mencapainya siswa/mahasiswa harus memiliki semangat atau dorongan yang disebut motivasi untuk mencapainya (Uno, 2015).

Menurut Sunaryo (2013), motivasi menunjukkan pada proses gerakan, termasuk situasi yang mendorong dan timbul dalam diri individu, serta tingkah laku yang ditimbulkan oleh situasi tersebut dan tujuan atau akhir dari gerakan atau perbuatan. Belajar yang dilandasi motivasi yang kuat dan berasal dari dalam individu, akan memperlancar proses belajar atau sebaliknya.

Sebagaimana yang dikutip oleh Kompri (2016), mengatakan bahwa motivasi adalah suatu perubahan energi di dalam pribadi seseorang yang ditandai dengan timbulnya afektif dan reaksi untuk mencapai tujuan. Perubahan energi dalam diri seseorang dapat berbentuk suatu aktivitas nyata berupa kegiatan fisik, maka seseorang harus memiliki motivasi yang kuat untuk mencapainya. Motivasi dan belajar merupakan dua hal yang saling memengaruhi, motivasi sangat menentukan tingkat berhasil atau gagalnya perbuatan belajar. Penelitian oleh Sutrisno (2011), bahwa salah satu hal yang sangat berpengaruh terhadap prestasi belajar di sekolah adalah motivasi belajar. Motivasi belajar yang tinggi berkorelasi dengan hasil belajar yang baik, sehingga berbagai upaya perlu dilakukan untuk meningkatkan motivasi belajar. Jika motivasi belajar siswa dapat ditingkatkan maka prestasi belajarnyapun akan meningkat pula.

Pemilihan jurusan bagi siswa sekolah menengah merupakan awal dari pemilihan karir seseorang, hal ini dikarenakan pemilihan jurusan tersebut akan mengantarkan pada 
penjurusan studi lanjut sebelum akhirnya menentukan dan memilih pekerjaan atau karir ke depan. Maka sekolah memegang peranan penting dalam mengembangkan potensi siswa, Pemilihan jurusan di sekolah menengah akan sangat menentukan pada tinggi rendahnya prestasi belajar pada jenjang selanjutnya atau dapat menyebabkan kegamangan dalam aktualisasi (Widayanti, 2009).

Berdasarkan pengamatan awal peneliti terhadap mahasiswa Akper Panti Kosala Surakarta pada belajarnya, adalah pencapaian hasil belajar yang berwujud prestasi belajar. Peneliti ingin mengetahui faktor apa saja yang berkontribusi pada prestasi belajar mahasiswa, pertama pada motivasi belajar dengan kategori motivasi rendah dan tinggi. Kedua, pada metode pembelajaran yang telah dikembangkan dan diterapkan diantaranya adalah ceramah yang merupakan metode TCL (Teacher Centered Learning) dan latihan, diskusi/PBL (Problem Based Learning), demontrasi serta penugasan merupakan metode SCL (Student Centered Learning). Ketiga, faktor yang perlu dikaji adalah menyangkut latar belakang jurusan di sekolah menengah. Selama ini ketiga faktor di atas belum pernah dikaji/dilakukan penelitian untuk mengetahui faktor yang berpengaruh pada prestasi belajar mahasiswa Akper Panti Kosala Surakarta. Terkait dengan hal tersebut, peneliti tertarik untuk melakukan penelitian tentang "Kontribusi Metode Pembelajaran, Motivasi Belajar dan Latar Belakang Jurusan di Sekolah Menengah terhadap Prestasi Belajar Mahasiswa Akper Panti Kosala Surakarta".

\section{TUJUAN PENELITIAN}

Secara umum penelitian ini bertujuan untuk mengetahui kontribusi metode pembelajaran, motivasi belajar dan latar belakang jurusan di sekolah menengah terhadap prestasi belajar mahasiswa Akper Panti Kosala Surakarta. Dan secara khusus penelitian ini bertujuan untuk mengetahui jenis metode pembelajaran yang diterapkan pada mahasiswa, tingkat motivasi belajar mahasiswa, latar belakang jurusan di sekolah menengah mahasiswa, tingkat prestasi belajar mahasiswa, hubungan metode pembelajaran yang diterapkan dengan prestasi belajar pada mahasiswa, hubungan motivasi belajar dengan prestasi belajar pada mahasiswa, serta hubungan latar belakang jurusan di sekolah menengah dengan prestasi belajar pada mahasiswa Akper Panti Kosala Surakarta.

\section{DESAIN PENELITIAN}

Dalam rancangan penelitian ini melibatkan dua variabel yang bertujuan untuk mengkaji hubungan metode pembelajaran, motivasi belajar dan latar belakang jurusan di sekolah menengah sebagai variabel bebas (independent variable) dengan prestasi belajar sebagai variabel terikat (dependent variable).

\section{POPULASI, SAMPEL, DAN TEHNIK SAMPLING}

Populasi pada penelitian ini adalah mahasiswa tingkat I dan II Akper Panti Kosala Surakarta yang berjumlah 276 orang. Adapun sampel dalam penelitian ini adalah mahasiswa tingkat I dan II Akper Panti Kosala Surakarta yang berjumlah 162 orang, yang diperoleh berdasarkan tabel krecjie. Dalam penelitian ini, peneliti menggunakan tehnik pengambilan sampel dengan teknik acak sederhana atau simple random sampling. 
HASIL PENELITIAN

1. Karakteristik Responden

Tabel 1

Distribusi Karakteristik

Responden Berdasarkan Jenis Kelamin dan Usia

\begin{tabular}{lccc}
\hline $\begin{array}{l}\text { Karakte } \\
\text { ristik }\end{array}$ & Kategori & $\mathrm{f}$ & $\%$ \\
\hline Jenis & Laki-Laki & 34 & 21 \\
Kelamin & Perempuan & 128 & 79 \\
Usia & 18 tahun & 46 & 28.4 \\
& 19 tahun & 64 & 39.5 \\
& 20 tahun & 47 & 29.0 \\
& 21 tahun & 4 & 2.5 \\
& 22 tahun & 1 & 0.6 \\
\hline
\end{tabular}

Dari tabel 1. menunjukkan bahwa sebagian besar responden berjenis kelamin perempuan berjumlah 128 orang (79\%) dan yang berjenis kelamin laki-laki berjumlah 34 orang (21\%). Sedangkan karakteristik berdasarkan usia sebagian besar responden berusia 19 tahun berjumlah 64 orang $(39.5 \%)$ dan yang berusia paling sedikit adalah 22 tahun berjumlah 1 orang $(0.6 \%)$.

2. Analisa Univariat tiap variabel

Tabel 2.

Distribusi Frekuensi Tiap Variabel

\begin{tabular}{cccc}
\hline Variabel & Kategori & $\mathrm{f}$ & $\%$ \\
\hline Metode & TCL & 38 & 23.5 \\
Belajar & SCL & 124 & 76.5 \\
& & & \\
Motivasi & Tinggi & 122 & 75.3 \\
Belajar & Rendah & 40 & 24.7 \\
& & & \\
Latar & Eksak & 66 & 40.7 \\
$\begin{array}{c}\text { Belakang } \\
\text { Jurusan }\end{array}$ & Non & 96 & 59.3 \\
SMA & Eksak & & \\
& & & \\
$\begin{array}{c}\text { Prestasi } \\
\text { Belajar }\end{array}$ & Tinggi & 118 & 72.8 \\
\hline
\end{tabular}

Dari tabel 2. dapat diperoleh data bahwa:

a. Metode belajar yang paling disukai dan tepat untuk mahasiswa adalah metode
SCL sejumlah 124 orang $(76.5 \%)$ sedang metode yang kurang disukai mahasiswa adalah TCL sejumlah 38 orang (23.5\%).

b. Responden yang memiliki motivasi tinggi sejumlah 122 orang ( $75.3 \%)$, sedangkan yang memiliki motivasi belajar rendah sejumlah 40 orang $(24.7 \%)$.

c. Responden yang berlatar belakang jurusan non eksak yaitu 96 orang (59.3\%), sedangkan latar belakang jurusan eksak yaitu 66 orang (40.7\%).

d. Responden yang memiliki prestasi belajar tinggi sejumlah 118 orang (72.8\%), sedangkan yang memiliki prestasi belajar rendah sejumlah 44 orang $(27.2 \%)$.

3. Analisa Bivariat

Tabel 3.

Tabulasi Silang Tiap Variabel terhadap Prestasi Belajar

\begin{tabular}{ccccc}
\hline \multirow{2}{*}{ Variabel } & \multirow{2}{*}{$\begin{array}{c}\text { Kate } \\
\text { gori }\end{array}$} & \multicolumn{3}{c}{ Prestasi Belajar } \\
\cline { 3 - 5 } & & $\mathrm{R}$ & $\mathrm{T}$ & Total \\
\hline \multirow{3}{*}{ Metode } & TCL & 16 & 22 & 38 \\
Belajar & SCL & $(42.1)$ & $(57.9)$ & $(100)$ \\
& & $(22.6)$ & $(77.4)$ & $(100)$ \\
& Rendah & 18 & 22 & 40 \\
Motivasi & & $(45.0)$ & $(55)$ & $(100)$ \\
Belajar & Tinggi & 26 & 96 & 122 \\
& & $(21.3)$ & $(78.7)$ & $(100)$ \\
Latar & Eksakta & 8 & 58 & 66 \\
Belakang & & $(12.1)$ & $(87.9)$ & $(100)$ \\
Jurusan & Non & 36 & 60 & 96 \\
& Eksakta & $(37.5)$ & $(62.5)$ & $(100)$ \\
\hline
\end{tabular}

Berdasarkan tabel 3 dapat dilihat bahwa :

a. Kontribusi variabel metode belajar pada prestasi belajar

1) Terdapat responden yang menyukai metode pembelajaran TCL (Teacher Centered Learning) 38 orang, 16 orang $(42.1 \%)$ memiliki 
prestasi belajar rendah dan 22 orang $(57.9 \%)$ memiliki prestasi belajar tinggi.

2) Terdapat responden yang menyukai metode pembelajaran SCL (Student Centered Learning) 124 orang, 44 orang (22.6\%) memiliki prestasi belajar rendah dan 118 orang (77.4\%) memiliki prestasi belajar tinggi.

3) Hasil uji dengan menggunakan Chi Square dengan $\alpha=5 \% \quad(0,05)$ diperoleh $p=0,018$ menunjukkan bahwa ada hubungan antara kedua variabel.

b. Kontribusi variabel motivasi belajar pada prestasi belajar:

1) Terdapat responden yang memiliki motivasi rendah 40 orang, 18 orang (45\%) memiliki prestasi belajar rendah dan 22 orang (55\%) memiliki prestasi belajar tinggi.

2) Terdapat responden yang memiliki motivasi tinggi 122 orang, 26 orang (21.3\%) memiliki prestasi belajar rendah dan 96 orang $(78.7 \%)$ memiliki prestasi belajar tinggi.

3) Hasil uji dengan menggunakan Chi Square dengan $\alpha=5 \% \quad(0,05)$ diperoleh $p=0,003$ menunjukkan bahwa ada hubungan antara kedua variabel.

c. Kontribusi variabel latar belakang jurusan di SMA pada prestasi belajar

1) Terdapat responden yang memiliki latar belakang jurusan eksakta 66 orang, 8 orang $(12.1 \%)$ memiliki prestasi belajar rendah dan 58 orang $(87.9 \%)$ memiliki prestasi belajar tinggi.
2) Terdapat responden yang memiliki latar belakang non eksakta 96 orang, 36 orang (37.5\%) memiliki prestasi belajar rendah dan 60 orang $(62.5 \%)$ memiliki prestasi belajar tinggi.

3) Hasil uji dengan menggunakan Chi Square. dengan $\alpha=5 \% \quad(0,05)$ diperoleh $p=0,000$ menunjukkan hubungan antara kedua variabel

4. Analisa Multivariat

Berdasarkan hasil bivariat maka semua variabel menunjukkan hasil $p<0.05$ maka semua variabel dapat dianalisis dengan uji multivariat karena $\mathrm{p}<0.25$.

Tabel 4.

Hasil Analisa Multivariat Regresi Logistik Ganda

\begin{tabular}{ccccc}
\hline Variabel & \multicolumn{3}{c}{ Cl 95\% } & $p$ \\
\cline { 3 - 4 } Independen & OR $\begin{array}{c}\text { Batas } \\
\text { Bawah }\end{array}$ & $\begin{array}{c}\text { Batas } \\
\text { Atas }\end{array}$ & \\
\hline $\begin{array}{c}\text { Metode } \\
\text { Pembela } \\
\text { Jaran }\end{array}$ & 0.41 & 0.18 & 0.92 & 0.029 \\
$\begin{array}{c}\text { Motivasi } \\
\text { Belajar } \\
\text { Latar } \\
\text { belakang }\end{array}$ & 0.48 & 0.21 & 1.09 & 0.077 \\
$\begin{array}{c}\text { Jurusan di } \\
\text { SMA }\end{array}$ & 1.59 & 9.00 & 0.003 \\
\hline $\begin{array}{c}\text { Nagelkerke } \\
R \text { Square }\end{array}$ & $18.7 \%$ & & & \\
\hline $\begin{array}{c}\text { Berdasarkan } \\
\text { menunjukkan: }\end{array}$ & tabel & 4. \\
\end{tabular}

a. Adanya pengaruh metode pembelajaran terhadap prestasi belajar mahasiswa. $(\mathrm{OR}=0.41, \mathrm{p}=0.029$ dan $\mathrm{p}<$ 0.05).

b. Tidak ada pengaruh motivasi belajar terhadap prestasi belajar mahasiswa. (OR= $0.48, p=0.077$ dan $p>0.05$ ).

c. Adanya pengaruh antara latar belakan jurusan di sekolah menengah terhadap prestasi belajar mahasiswa. (OR= $3.78, p=0.003$ dan $p<0.05$ ) 
d. Bahwa hasil penelitian menunjukkan variabel independen mempengaruhi variabel dependen dengan nilai Nagelkerke $R$ Square $18.7 \%$ artinya bahwa variabel metode pembelajaran, motivasi belajar dan latar belakang jurusan di sekolah menengah secara bersamasama mempengaruhi prestasi belajar sebesar $18.7 \%$ dan sisanya yang $81.3 \%$ dipengaruhi variabel lain di luar penelitian.

\section{PEMBAHASAN}

1. Variabel Metode Pembelajaran terhadap Prestasi Belajar

Berdasarkan analisis univariat dari tabel 2, sebagian besar mahasiswa menyukai metode belajar SCL (Student Centered Learning) yaitu sebesar $76,5 \%$. Metode belajar adalah suatu cara yang digunakan oleh pengajar agar siswa dapat belajar seluasluasnya dalam rangka mencapai tujuan pengajaran secara efektif (Wahab, 2015). Maka di dalam metode belajar pengajar harus mampu merencanakan langkahlangkah pembelajaran sekaligus melakukan metode evaluasi yang akan dilakukan. Demikian halnya yang dikemukakan oleh Warsono dan Hariyanto ( 2014) bahwa belajar dengan melakukan atau learning by doing yaitu metode belajar SCL (Student Centered Learning) memberi makna siswa harus aktif dalam berbagai pembicaraan pembelajaran, demikian pula pada hasil penelitian Widodo (2013) bahwa penerapan metode belajar kolaboratif berdampak positif dalam meningkatkan keaktifan siswa baik dari ranah afektif maupun psikomotoris. Karena setiap pilihan pada metode pembelajaran harus memberi output yang baik pada siswa, maka pengajar harus bijak dalam menentukan pengelolaan di kelas.

Pada tabel 2 ini juga didapatkan $23.5 \%$ mahasiswa yang menyukai metode belajar TCL, metode belajar tersebut merupakan pendekatan pembelajaran yang didominasi oleh pengajar/guru sehingga dikatakan pembelajaran berbasis guru (Warsono dan Hariyanto, 2014). Terkait dengan model pembelajaran TCL biasanya dengan menerapkan metode ceramah, dimana peran guru lebih aktif dibanding siswa karena proses komunikasi berjalan satu arah yakni dari guru ke siswa sehingga keuntungan lebih cenderung kepada guru antara lain mudah menguasai kelas dan mudah dilaksanakan tetapi di pihak lain kelemahannya siswa menjadi pasif sehingga cepat bosan dan guru tidak mampu mengontrol sejauh mana perolehan belajar siswa (Hamid, 2011). Maka yang perlu dipahami oleh setiap pengajar bahwa pilihan metode ceramah (TCL) tidak semata-mata karena kehebatan guru dalam mengolah kata/kalimat tetapi juga perlu dukungan media seperti gambar, slide, dan fasilitas pembelajaran yang tersedia di kelas.

Dari hasil uji bivariat dapat diperoleh $p=0,018$ dan $p<0.05$ artinya ada hubungan antara metode pembelajaran dengan prestasi belajar, hal ini dapat dilihat pada tabel 3 . dari 124 orang mahasiswa yang menyukai metode belajar SCL terdapat $77.4 \%$ mahasiswa mampu mencapai prestasi belajar tinggi, hal ini sesuai yang diungkapkan pada penelitian Mukhlisoh dan Aisah (2013) bahwa metode problem solving (salah satu dari metode SCL) memberi pengaruh positif dan 
signifikan terhadap proses belajar siswa. Menurut Uno (2015) bahwa metode pembelajaran harus menaruh perhatian pada upaya meningkatkan pemahaman dan memperbaiki proses pembelajaran sehingga menghasilkan output belajar berupa prestasi belajar yang diharapkan, karena hal demikian maka metode belajar harus diciptakan dengan melibatkan siswa/mahasiswa seluasluasnya. Karena metode belajar TCL merupakan metode yang konvensional maka seharusnya mulai diubah menjadi metode SCL yang berpusat pada peserta didik, dan metode SCL seharusnya lebih banyak dikembangkan karena metodenya bervariatif antara lain diskusi, tanya jawab, demontrasi, penugasan dan PBL (pembelajaran berbasis masalah) yang memiliki keuntungan antara lain siswa menjadi lebih aktif dengan harapan siswa dapat menyerap materi lebih optimal, dapat memberi pendapat secara konstruktif, dapat bekerjasama dalam kelompok dan sebagainya. Hasil uji bivariat tersebut dikuatkan dengan hasil uji multivariat dengan $p=0.029$ dan $\mathrm{p}<0.05$, maka metode pembelajaran berpengaruh terhadap prestasi belajar. Sebagaimana yang dikutip oleh Sunaryo (2013) bahwa prestasi belajar merupakan hal yang tidak dapat dipisahkan dari kegiatan belajar (termasuk di dalamnya metode belajar yang diterapkan), karena suatu proses belajar harus memberi hasil belajar. Dan hasil belajar yang baik diperoleh apabila dalam menyampaikan materi guru dapat menerapkan metode belajar yang sesuai dengan karakteristik siswa, metode pembelajaran tertentu pada kelompok subyek yang berbeda karakteristiknya akan memberi hasil belajar yang berbeda.

2. Variabel Motivasi Belajar terhadap Prestasi Belajar

Dari tabel 2 diperoleh hasil terdapat $75.3 \%$ responden memiliki motivasi tinggi. Dalam hal ini, motivasi berarti sesuatu yang mendorong untuk berbuat, semua hal verbal, fisik, atau psikologis yang membuat seseorang melakukan sesuatu sebagai respon, sementara sebagaimana dikutip oleh Sunaryo (2013) bahwa motivasi menunjuk pada suatu proses, termasuk situasi yang mendorong dan timbul dalam diri individu, serta tingkah laku yang ditimbulkan oleh situasi tersebut. Belajar yang dilandasi motivasi yang kuat dan berasal dari dalam individu, akan memperlancar proses belajar atau sebaliknya. Pada tabel 2 terdapat $24.7 \%$ mahasiswa memiliki motivasi belajar rendah berarti tidak ada dorongan untuk melakukan suatu perbuatan belajar yang ada kemungkinan karena pengaruh faktor diri sendiri, tidak ada cita cita yang didambakan serta tidak percaya diri.

Dari hasil uji bivariat dapat diperoleh $p=0.003$ dan $p<0.05$ artinya ada hubungan antara motivasi belajar dengan prestasi belajar. Dari tabel 3 terdapat 122 orang yang memiliki motivasi tinggi, $78.7 \%$ orang mampu mencapai prestasi tinggi. Jadi semakin tinggi motivasi belajar seseorang maka akan memperlancar proses belajar yang dengan sendirinya akan memberi hasil belajar berupa prestasi belajar yang baik. Hal ini sejalan dengan yang dikemukakan oleh Wahab (2015) bahwa motivasi belajar akan menjadi pendorong, penggerak dan pengarah perbuatan yang 
dapat menyelesaikan dan menentukan perbuatan apa yang harus dilakukan. Motivasi belajar merupakan faktor yang mendasar dan mendorong siswa ke sejumlah perbuatan belajar yang pada akhirnya memberi hasil yang baik. Motivasi dan belajar merupakan dua hal yang saling memengaruhi, motivasi sangat menentukan tingkat berhasil tidaknya perbuatan belajar (Kompri, 2016). Sebagaimana penelitian yang telah dilakukan oleh Sutrisno (2011), bahwa salah satu hal yang sangat berpengaruh terhadap prestasi belajar di sekolah adalah motivasi belajar. Motivasi belajar yang tinggi berkorelasi dengan hasil belajar yang baik, sehingga berbagai upaya perlu dilakukan untuk meningkatkan motivasi belajar. Jika motivasi belajar dapat ditingkatkan maka prestasi belajarnyapun akan meningkat pula. Jadi motivasi merupakan dorongan psikologis yang memberi kekuatan yang tak terbendung untuk melahirkan sikap belajar.

Hasil Uji bivariat di atas, berbeda dengan hasil uji multivariat yang menunjukkan $p=0.077$ dan $p>$ 0.05 , artinya motivasi belajar tidak berpengaruh terhadap prestasi belajar, hal ini ada kemungkinan karena pada uji multivariat bersama -sama dengan variabel lain sehingga ada variabel lain yang pengaruhnya lebih kuat. Motivasi munculnya dalam diri seseorang bentuknya perubahan di dalam yang berbentuk afektif sehingga sangat sulit dilihat secara obyektif sebagaimana kutipan yang disampaikan oleh Kompri (2016) bahwa motivasi adalah suatu perubahan energi di dalam pribadi seseorang yang ditandai dengan timbulnya afektif dan reaksi untuk mencapai tujuan.
Perubahan energi dalam diri seseorang dapat berbentuk suatu aktivitas nyata berupa kegiatan fisik. Maka apabila muncul perubahan energi belajar yang terwujud dalam bentuk kegiatan fisik tersebut diduga akan mendorong siswa menentukan metode belajarnya yang berpengaruh terhadap prestasi belajar. Dengan demikian motivasi belajar tidak berpengaruh pada prestasi belajar karena terdapat variabel metode belajar yang mempengaruhinya. sebagaimana hasil penelitian Purwatiningsih dan Harnoto (2013) menyimpulkan bahwa motivasi belajar dapat memediasi metode pembelajaran terhadap prestasi belajar. Dari penelitian tersebut menunjukkan bahwa motivasi dapat memediasi metode belajar, artinya motivasi belajar berkaitan erat dengan metode belajar siswa.

3. Variabel Latar Belakang Jurusan di Sekolah Menengah terhadap Prestasi Belajar

Pemilihan jurusan bagi siswa sekolah menengah merupakan awal dari pemilihan karir seseorang ke depannya, hal ini dikarenakan pemilihan jurusan tersebut akan mengantarkan pada penjurusan studi lanjut sebelum akhirnya menentukan, memilih pekerjaan atau karir ke depannya. Sebagaimana yang dikemukakan oleh Widayanti (2009) bahwa sekolah memegang peranan penting dalam mengembangkan potensi. Berdasarkan tabel 3 diperoleh hasil dari 66 orang yang berlatar belakang jurusan eksak, $87.9 \%$ mencapai prestasi tinggi dan $12.1 \%$ mencapai prestasi rendah sedangkan yang berlatar belakang jurusan non eksak sejumlah 96 orang, $62.5 \%$ mencapai prestasi tinggi dan 
$37.5 \%$ mencapai prestasi rendah. Hasil dari uji bivariat diperoleh $p$ $=0.000$ dan uji multivariat $p=$ 0.003 , baik uji bivariat maupun uji multivariat memberi hasil $p<0.05$, maka hal ini menunjukkan ada hubungan maupun pengaruh antara latar belakang jurusan di sekolah menengah dengan prestasi belajar. Hal ini dapat disimpulkan bahwa semakin banyak yang berlatar belakang jurusan eksak maka prestasi mahasiswa keperawatan akan semakin baik, karena materi pembelajaran keperawatan lebih cenderung pada bidang eksak Sebagaimana yang disampaikan oleh Widayanti (2009) bahwa pemilihan dalam penjurusan di sekolah menengah akan menentukan tinggi rendahnya prestasi belajar.

4. Kontribusi Metode Pembelajaran, Motivasi Belajar dan Latar Belakang Jurusan di Sekolah Menengah terhadap Prestasi Belajar

Prestasi belajar adalah keberhasilan yang dicapai dari suatu kegiatan atau usaha yang dapat memberikan keputusan emosional dan dapat diukur dengan alat atau tes tertentu (Wahab, 2015). Pada prinsipnya, pengungkapan hasil belajar ideal meliputi segenap ranah psikologis yang berubah sebagai akibat pengalaman dan proses belajar siswa. Sedang pengungkapan perubahan tingkah laku seluruh ranah itu, khususnya ranah siswa, sangat sulit. Hal ini disebabkan perubahan hasil belajar itu ada yang bersifat intagible (tak dapat diraba). Oleh karena itu, yang dapat dilakukan guru dalam hal ini adalah hanya mengambil cuplikan perubahan tingkah laku yang dianggap penting dan diharapkan dapat mencerminkan perubahan yang terjadi sebagai hasil belajar siswa, baik yang berdimensi cipta dan karsa (Syah, 2012). Pada uji multivariat tabel 4. menunjukkan bahwa latar belakang jurusan di sekolah menengah memiliki pengaruh yang paling kuat terhadap prestasi belajar yakni dengan OR $=3.78$, artinya mahasiswa yang berlatar belakang eksak memiliki kemungkinan untuk mencapai prestasi tinggi sebesar 3.78 kali lebih tinggi dibanding yang memiliki latar belakang jurusan non eksak. Maka pemilihan jurusan di sekolah menengah yang asal-asalan akan menyebabkan kegamangan dalam aktualisasi diri, tak jarang siswa yang tidak mengerti alasan pemilihan jurusan maka setelah tamat tidak mengetahui akan sekolah dimana atau tidak mengetahui cita-citanya (Widayanti, 2009).

Adapun faktor-faktor yang mempengaruhi prestasi belajar sebagaimana dikutip oleh Wahab (2015) adalah:

a. Faktor internal (faktor dari dalam diri siswa) yang terdiri dari faktor fisiologi (keadaan fisik dan asupan gizi siswa) dan faktor psikologis (IQ, perhatian, minat, motivasi, dan bakat).

b. Faktor eksternal (faktor dari luar anak), yakni kondisi lingkungan sekitar anak antara lain : faktor sosial (lingkungan keluarga, sekolah dan masyarakat) dan faktor non sosial (meliputi keadaan dan letak gedung sekolah, keadaan dan letak rumah tempat tinggal, alat-alat dan sumber belajar, keadaan cuaca dan waktu belajar yang digunakan).

c. Faktor pendekatan belajar (approach to learning), yakni jenis upaya belajar peserta didik yang meliputi strategi 
dan metode pembelajaran yang digunakan anak dalam mengikuti pembelajaran.

Dalam penelitian ini yang digunakan sebagai variabel independen hanya 3 (tiga) faktor/variabel saja dari banyaknya faktor yang menentukan prestasi belajar. Oleh karenanya metode pembelajaran, motivasi belajar dan pemilihan jurusan di sekolah menengah berkontribusi pada prestasi belajar sebesar $18.7 \%$ dan sisanya yang $81.3 \%$ dipengaruhi oleh faktor lain yang tidak diteliti antara lain keadaan fisik, asupan gizi, IQ, perhatian, bakat, lingkungan keluarga, sekolah dan masyarakat, keadaan dan letak gedung sekolah, keadaan dan letak rumah tempat tinggal, alat-alat dan sumber belajar, keadaan cuaca dan waktu belajar yang digunakan, hal ini dikuatkan oleh hasil penelitian dari Syatyawati (2013) bahwa gizi siswa memiliki hubungan yang signifikan dengan prestasi belajar anak, demikian juga dari hasil penelitian Ariwibowo (2013) bahwa lingkungan belajar memiliki hubungan yang signifikan dengan prestasi belajar.

\section{KESIMPULAN}

Kesimpulan dari penelitian di atas adalah sebagai berikut :

1. Terdapat $76.5 \%$ menyukai metode SCL (Student Centered Learning) dan $23.5 \%$ menyukai TCL (Teacher Centered Learning)

2. Terdapat $75.3 \%$ memiliki motivasi tinggi dan $24.7 \%$ memiliki motivasi rendah.

3. Terdapat $40.7 \%$ dari jurusan eksak dan $59.3 \%$ dari jurusan non eksak.

4. Metode pembelajaran berkontribusi pada prestasi belajar $(p=0.029$ dan $p<0.05)$.
5. Motivasi belajar tidak berkontribusi pada prestasi belajar $(p=0.077$ dan $p<0.05)$.

6. Latar belakang jurusan di sekolah menengah berkontribusi pada prestasi belajar $(p=0.003$ dan $p$ $<0.05)$.

7. Bahwa hasil penelitian menunjukkan variabel independen mempengaruhi variabel dependen dengan nilai Nagelkerke $R$ Square 18.7\% artinya bahwa variabel metode pembelajaran, motivasi belajar dan pemilihan jurusan di sekolah menengah secara bersama-sama mempengaruhi prestasi belajar sebesar $18.7 \%$ dan sisanya yang $81.3 \%$ dipengaruhi variabel lain di luar penelitian antara lain keadaan fisik, asupan gizi, IQ, perhatian, bakat, lingkungan keluarga, sekolah dan masyarakat, keadaan dan letak gedung sekolah, keadaan dan letak rumah tempat tinggal, alatalat dan sumber belajar, keadaan cuaca dan waktu belajar yang digunakan.

\section{SARAN}

1. Mahasiswa akan memiliki prestasi baik, bila dapat memilih dan menentukan metode belajar yang tepat dalam menyerap materi, dan terus berusaha meningkatkan motivasi belajar.

2. Bagi institusi pendidikan keperawatan, dapat melakukan seleksi mahasiswa baru yang lebih diprioritaskan pada calon mahasiswa yang berlatar belakang jurusan eksak agar prestasi belajarnya baik.

3. Untuk peneliti selanjutnya diharapkan dapat mengembangkan faktor-faktor lain yang belum diteliti yang memiliki pengaruh pada prestasi belajar. 
DAFTAR PUSTAKA

Ariwibowo, M. S. 2013. Pengaruh Lingkungan Belajar terhadap Prestasi Belajar Mahasiswa PPKn Angkatan 2008/2009 Universitas Ahmad Dahlan Semester Ganjil TA 2010/2011. Http:// Jurnal Citizenship Vol 1, No. 2 2012. jogjapress.com. pdf. Diakses tanggal 10 Oktober 2016.

Hamid, M. S. 2011. Metode Edutainment. Diva Press, Jogyakarta.

Kompri. $2016 . \quad$ Motivasi Pembelajaran: Perspektif Guru dan Siswa. PT Remaja Rosdakarya, Bandung.

Mukhlisoh, dan S. Aisyah. 2013. Pengaruh Penerapan Metode Problem Solving terhadap Motivasi Belajar Siswa Dalam Mata Pelajaran IPS Kelas IV MI PUI Cikaso Kecamatan Kramatmulya Kabupaten Kuningan. URL: https://www.google.co.id. Diakses Tanggal 3 Oktober 2016.

Nurhuda, A. 2012. Pengaruh Metode Mengajar Guru terhadap Prestasi Belajar. https://www.google.co.id. Diakses Tanggal 3 Oktober 2016.

Purwatiningsih, T. dan Hartono. 2013. Analisis Pengaruh Metode Pembelajaran dan Lingkungan Sekolah terhadap Prestasi Belajar Peserta Didik dengan Motivasi Belajar Sebagai Variabel Mediasi. URL : http://digilib.uinsuka.ac.id.pdf. Diakses Tanggal 5 Oktober 2016.

Sunaryo. 2013. Psikologi Untuk Keperawatan. Buku Kedokteran EGC, Jakarta.

Sutrisno, J. 2011. Pengaruh Metode Pembelajaran Inquiry dalam Belajar Sains terhadap Motivasi Belajar. Http.// skp.unair. ac.id.pdf. Diakses tanggal 10 Oktober 2016.
Syatyawati, R. 2013. Hubungan antara Status Gizi dengan Prestasi Belajar Anak Sekolah Dasar di Desa Grenggeng Karanganyar Kebumen. URL: http://eprints. Ums.ac.id/pdf. Diakses pada tanggal 7 Oktober 2016.

Syah, M. 2012. Psikologi Belajar. PT Raja Grafindo Persada, Jakarta.

Undang-Undang RI Nomor 20 tahun 2003. 2013. Sistem Pendidikan Nasional. Fokusmedia, Bandung.

Uno, H. B. 2015. Model Pembelajaran: Menciptakan Proses Belajar Mengajar yang Kreatif dan Efektif. PT Bumi Aksara, Jakarta.

Wahab, Rohmalina. 2015. Psikologi Belajar. Rajawali Press, Jakarta.

Warsono dan Hariyanto. 2014. Pembelajaran Aktif. PT Remaja Rosdakarya, Bandung.

Widayanti, Ninik. 2009. Bimbingan dan Konseling Online. URL:http://bimbingan karir.wordpress.com. Diakses 5 Oktober 2016.

Widodo, Urip. 2013. Penerapan Metode Pembelajaran Kolaboratif untuk Meningkatkan Prestasi Belajar Siswa pada Mata Pelajaran Membaca Gambar Sketsa di SMK Negeri 2 Klaten. Skripsi universitas Negeri Yogjakarta. https://www.google.co.id. Diakses tanggal 2 Oktober 2016.

${ }^{1}$ Dosen AKPER Panti Kosala
Surakarta
${ }^{2}$ Mahasiswa AKPER Panti Kosala
Surakarta

